\title{
Effect of carbon dioxide on the growth and form of Candida albicans
}

\author{
W. SIMS
}

The Dental School, University College, London, Mortimer Market, London WC1E 6JD

Summary. The effect of $\mathrm{CO}_{2}$ on the growth of 31 strains of Candida albicans was studied in serum and in a defined medium containing urea, ammonium chloride, asparagine, glutamine or acetamide as the nitrogen source. $\mathrm{CO}_{2} 10 \%$ enhanced the mycelial growth of all strains when the medium contained an appropriate constituent to mediate its effect. The effect of $\mathrm{CO}_{2}$ was most clearly demonstrated at $30^{\circ} \mathrm{C}$ when it induced a characteristic growth form consisting of a single swollen blastospore giving rise to a long, unbranched mycelial tube with few secondary blastospores; in atmospheric concentrations of $\mathrm{CO}_{2}$ only blastospore growth occurred. Growth in the blastospore form was more rapid in $\mathrm{CO}_{2} 10 \%$ than in air. Bicarbonate ions had no effect on mycelium formation. The result suggest that the induction of germ-tubes and mycelial growth is essentially a physical phenomenon caused by the intracellular accumulation of $\mathrm{CO}_{2}$ in limited nutrient conditions, a view consistent with other reported laboratory and clinical findings.

\section{Introduction}

The literature describing the formation of germtubes and induction of the mycelial form of growth of Candida albicans is controversial and contradictory (reviewed by Odds, 1979). Much of this discrepancy seems to have arisen from studies employing only single strains of the organism or from the use of different criteria for assessing growth form. During a study of the growth of $C$. albicans in media of composition similar to that of human saliva, the finding of Odds and Abbott (1980) that urea serves as the sole source of nitrogen was confirmed, but it was also found to promote the formation of germ-tubes and subsequent growth in the mycelial form. Furthermore, this effect was greatly enhanced by incubation in atmospheres containing $\mathrm{CO}_{2} 5-10 \%$. In view of the prevailing disagreement in this field, the effect of $\mathrm{CO}_{2}$ on several strains of $C$. albicans was studied and a simple, unequivocal method of assessing growth form was used.

\section{Materials and methods}

\section{Strains of C. albicans}

Thirty-one strains were used: six were from normal mouths; four were associated with denture stomatitis;

Received 24 Jul. 1985; revised version accepted 20 Jan. 1986. three strains each were from candidiasis affecting the tongue and mucous membrane of the cheek; four strains were associated with angular cheilitis; and three were from juvenile thrush. Two strains were from the normal vagina and two were associated with vulvovaginitis. Strains nos. 3135 and 6406 were from the Mycological Reference Laboratory, London, and the remaining two were laboratory strains known to be reliable producers of germ-tubes and chlamydospores respectively. All 31 strains had been preserved from 2 months to 7 years on slopes of corn meal agar at $4^{\circ} \mathrm{C}$.

The strains were identified by tests for the formation of germ-tubes in serum (Taschdjian et al., 1960), the production of chlamydospores in corn meal agar containing Tween $801 \%$ (Rosenthal and Furnari, 1958) and by the reactions in API 20C auxanogram strips (API Laboratory Products, Basingstoke, Hampshire). Confluent growth of each strain was obtained on plates of Sabouraud agar (Oxoid) incubated at $37^{\circ} \mathrm{C}$ for $24 \mathrm{~h}$, and then

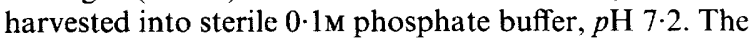
suspension was centrifuged at $500 \mathrm{~g}$ and the deposited cells washed twice in phosphate buffer and once in sterile distilled water. The cells were counted in a Helber chamber, suspended in sterile distilled water at a concentration of $20 \times 10^{6}$ cells $/ \mathrm{ml}$ and stored at $4^{\circ} \mathrm{C}$ until used.

\section{Media}

Stock solutions of $0 \cdot 2 \mathrm{M} \mathrm{K} \mathrm{K}_{2} \mathrm{HPO}_{4}, 0 \cdot 2 \mathrm{M} \mathrm{KH}_{2} \mathrm{PO}_{4}$, glucose $10 \%, \mathrm{MgSO}_{4} 5 \%$ and $\mathrm{CaCl}_{2} 0 \cdot 1 \%$ were prepared and sterilised by autoclaving at $121^{\circ} \mathrm{C}$ for $15 \mathrm{~min}$. Media were freshly prepared by dissolving $1 \mathrm{~g}$ of the appropriate 
nitrogen source, i.e., ammonium chloride, urea, asparagine, glutamine or acetamide in $50 \mathrm{ml}$ of distilled water and adding, where required. $1 \mathrm{~g}$ of powdered bovine serum albumin or globulin. All chemicals were obtained from the Sigma Chemical Company Ltd, Poole, Dorset. Next. $3.1 \mathrm{ml}$ of $\mathrm{K}_{2} \mathrm{HPO}_{4}$ solution. $1.9 \mathrm{ml}$ of $\mathrm{KH}_{2} \mathrm{PO}_{4}$ solution and $1 \mathrm{ml}$ of each of the glucose, $\mathrm{MgSO}_{4}$ and $\mathrm{CaCl}_{2}$ solutions were added and the volume made up to $100 \mathrm{ml}$. When the constituents were completely dissolved the media were sterilised by passage through a $0 \cdot 22-\mu \mathrm{m}$ membrane filter (Sterivex; Millipore). The $p \mathrm{H}$ values of the media were measured with a Radiometer Ion 85 analyser and an Ingold semi-micro combined reference and $p \mathrm{H}$ electrode; they were within the range $6 \cdot 8-7 \cdot 2$. Horse serum no, 3 (Wellcome Reagents Ltd) was used undiluted. All media were dispensed in $1-\mathrm{ml}$ amounts in sterile 7-ml plastic, screw-capped bijou vials (Sterilin Ltd, Feltham, Middx).

Glucose-agar plates consisted of Oxoid Agar No. $11^{\circ} \%$ containing glucose $0.1 \%$. They were inoculated as described by Joshi et al. (1975).

\section{Assessment of mycelial growth}

For each strain of C. albicans, $0.05 \mathrm{ml}$ of suspension was added to two vials of the appropriate medium and incubated with loose caps for $18 \mathrm{~h}$ at the test temperature: one vial was incubated in air and the other in $\mathrm{CO}_{2} 10^{\circ}$ in a Hotpack automatic $\mathrm{CO}_{2}$ incubator.

Wet preparations of each of the paired cultures were made on the same slide and examined by phase-contrast microscopy. When mycelial growth in the culture incubated in $\mathrm{CO}_{2}$ was grossly and unequivocally greater than that in the culture incubated in air the fact was recorded: lesser increases were ignored. The increased mycelial growth induced by $\mathrm{CO}_{2}$ was often of a novel form consisting of long, unbranched mycelial tubes with few or no secondary blastospores. When this type of growth predominated over the usual coarse, branched mycelium with associated secondary blastospores it was recorded.

Glucose-agar plates were examined after incubation for $5 \mathrm{~h}$ at $37^{\circ} \mathrm{C}$ in air, in air plus $\mathrm{CO}_{2} 10^{\circ}$, in polycarbonate anaerobic jars (Don Whitley Scientific Ltd, Shipley. W. Yorks) filled with $\mathrm{H}_{2}$ or $\mathrm{H}_{2} 90^{\circ}{ }_{\circ}, \mathrm{CO}_{2} 10_{\%}^{\circ}$.

\section{Effect of $\mathrm{CO}_{2}$ on growth.}

This was assessed with 22 strains that grew predominantly as blastospores in the medium with ammonium chloride as the nitrogen source. Four 1-ml cultures of each strain were incubated in air or air plus $\mathrm{CO}_{2} 10^{\circ}{ }_{\circ}$ at the appropriate temperature. After $4.8,12$ and $18 \mathrm{~h}$, vials were removed and the apparent absorbence at $420 \mathrm{~nm}$ was measured in a Pye Unicam SP6-500 spectrophotometer with a cuvette of $1-\mathrm{cm}$ light path.

\section{Estimation of protein}

Five $1-\mathrm{ml}$ cultures of each of the strains in the ammonium chloride bovine serum albumin broth were incubated, with uninoculated broths for comparison, at $37 \mathrm{C}$ for $18 \mathrm{~h}$. The cultures were pooled, centrifuged and the supernate passed through a $0 \cdot 45-\mu \mathrm{m}$ membrane filter (Millex; Millipore). The protein content of the supernates was measured with the reagents and protocol of the Sigma Chemical Co. kit no. 690. This method is a modification of that described by Ohnishi and Barr (1978) and reproducibility studies, quoted by Sigma, show it has a standard deviation of $0.3 \mathrm{mg} / 100 \mathrm{ml}$ for a sample containing protein $25 \mathrm{mg} / \mathrm{ml}$.

\section{Results}

\section{Effect of $\mathrm{CO}_{2}$ on growth in the mycelial form}

$\mathrm{CO}_{2}$ promoted mycelial growth of all the strains of $C$. albicans (table I). Except in media containing either urea or acetamide as the nitrogen source this effect was difficult to demonstrate at $37^{\circ} \mathrm{C}$ because growth in the mycelial form was already florid at atmospheric concentrations of $\mathrm{CO}_{2}$. In the numerous examinations made, enhancement of mycelial growth was apparent at $37^{\circ} \mathrm{C}$ but difficult to quantify and insufficient to satisfy the criterion adopted. A temperature of $37^{\circ} \mathrm{C}$ has generally been regarded as essential for germ-tube and mycelium formation but the effect of raising the partial pressure of $\mathrm{CO}_{2}$ was more readily demonstrable at $30 \mathrm{C}$ when germ-tubes and mycelium formed in abundance. A few strains grew in the mycelial form at $25 \mathrm{C}$ in horse serum (fig. 1). There was a marked tendency for $\mathrm{CO}_{2}$ to induce a particular type of mycelial growth consisting of a long, usually unbranched, mycelial tube originating from a swollen, roughly spherical blastospore with few or no secondary blastospores budding from the mycelium. Examples of strains isolated from the palate (P2) and from angular cheilitis (Acl) growing in media with asparagine and bovine serum albumin plus ammonium chloride, respectively, as the nitrogen sources are shown in figs. 2 and 3. In horse serum, branching was usual but secondary blastospores remained rare (fig. 1). Vacuolisation of the mycelial protoplasm (Gow and Gooday, 1984) is seen in fig. 4 which shows a strain isolated from a healthy mouth (N4) growing in the medium with urea as the source of nitrogen.

\section{Media constituents}

The results in table I show that raising the $\mathrm{CO}_{2}$ partial pressure alone was insufficient to induce mycelium formation; $\mathrm{CO}_{2}$ had no effect when the medium contained ammonium chloride as the source of nitrogen. The selection of compounds for testing arose from the finding that urea was a 
Table I. The effect on 31 strains of $C$. albicans of increasing the $\mathrm{CO}_{2}$ concentration from atmospheric to $10 \%$ with incubation at different temperatures in various media for $18 \mathrm{~h}$

\begin{tabular}{|c|c|c|c|c|}
\hline \multirow[b]{2}{*}{$\begin{array}{l}\text { Medium or nitrogen } \\
\text { source in medium }\end{array}$} & \multirow[b]{2}{*}{$\begin{array}{l}\text { Temperature } \\
\left({ }^{\circ} \mathrm{C}\right)\end{array}$} & \multicolumn{3}{|c|}{ Number of strains demonstrating } \\
\hline & & $\begin{array}{l}\text { Increase in growth } \\
\text { in the mycelial form }\end{array}$ & $\begin{array}{l}\text { Increase in coarse, } \\
\text { branched mycelium } \\
\text { with attached } \\
\text { secondary blastospores }\end{array}$ & $\begin{array}{l}\text { Increase in long, } \\
\text { unbranched mycelial } \\
\text { tubes with few } \\
\text { secondary blastospores }\end{array}$ \\
\hline Horse serum & $\begin{array}{l}37 \\
30^{*} \\
25^{*}\end{array}$ & $\begin{array}{r}0 \\
31 \\
12\end{array}$ & $\begin{array}{c}0 \\
0 \\
12 \dagger\end{array}$ & $\begin{array}{r}0 \\
31 \\
0\end{array}$ \\
\hline Ammonium chloride & $\begin{array}{l}37 \\
30^{*}\end{array}$ & $\begin{array}{l}0 \\
0\end{array}$ & $\begin{array}{l}0 \\
0\end{array}$ & $\begin{array}{l}0 \\
0\end{array}$ \\
\hline $\begin{array}{l}\text { Bovine albumin }+ \\
\text { ammonium chloride }\end{array}$ & $\begin{array}{l}37 \\
30^{*}\end{array}$ & $\begin{array}{r}0 \\
31\end{array}$ & $\begin{array}{l}0 \\
6\end{array}$ & $\begin{array}{r}0 \\
25\end{array}$ \\
\hline Urea & $\begin{array}{l}37 \\
30^{*}\end{array}$ & $\begin{array}{l}29 \\
29\end{array}$ & $\begin{array}{l}20 \\
15\end{array}$ & $\begin{array}{r}9 \\
14\end{array}$ \\
\hline Asparagine & $\begin{array}{l}37 \\
30^{*}\end{array}$ & $\begin{array}{r}0 \\
31\end{array}$ & $\begin{array}{r}0 \\
14\end{array}$ & $\begin{array}{r}0 \\
17\end{array}$ \\
\hline Glutamine & $\begin{array}{l}37 \\
30^{*}\end{array}$ & $\begin{array}{r}0 \\
31\end{array}$ & $\begin{array}{r}0 \\
14\end{array}$ & $\begin{array}{r}0 \\
17\end{array}$ \\
\hline Acetamide & $\begin{array}{l}37 \\
30^{*}\end{array}$ & $\begin{array}{l}15 \\
13\end{array}$ & $\begin{array}{l}15 \\
13\end{array}$ & $\begin{array}{l}0 \\
0\end{array}$ \\
\hline
\end{tabular}

* Growth in control cultures in air almost entirely in the blastospore form.

$\dagger$ Few secondary blastospores.

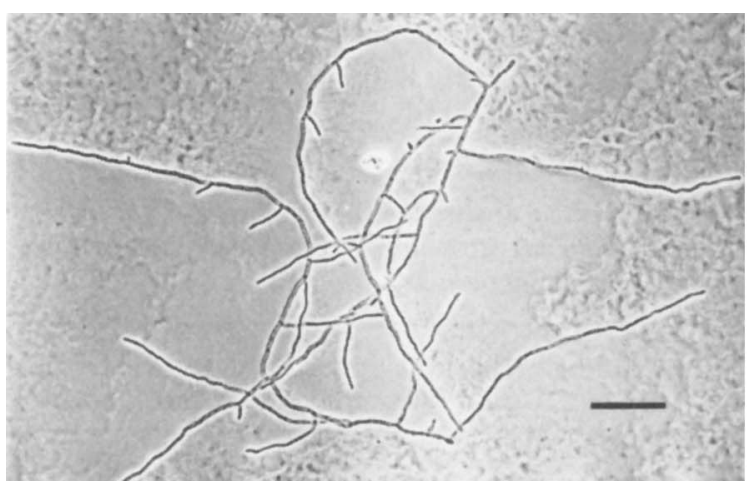

Fig. 1. C. albicans (Mycological Reference Laboratory strain no. 3135) incubated in horse serum for $18 \mathrm{~h}$ at $25^{\circ} \mathrm{C}$ in $\mathrm{CO}_{2} 10 \%$ showing branching mycelium but few secondary blastospores. Control culture in air consisted of blastospores only. Wet preparation. Bar $=50 \mu \mathrm{m}$.

satisfactory nitrogen source for $C$. albicans and promoted mycelial growth in media similar in composition to that of saliva. Urea is a di-amide; therefore acetamide and formamide were tested but the latter compound supported only slow and feeble growth. Sheperd et al. (1980) showed that glutamine induced germ-tubes and so it, together with the

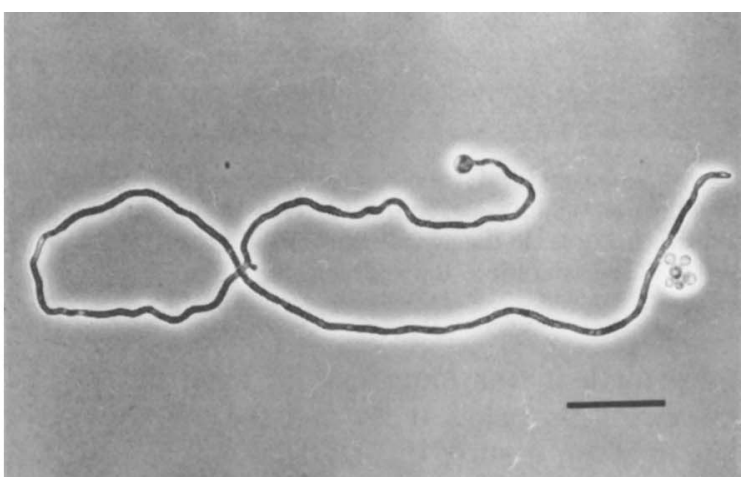

Fig. 2. C. albicans (oral strain $\mathrm{P} 2$ ) incubated in the basal medium with asparagine as the nitrogen source for $18 \mathrm{~h}$ at $30^{\circ} \mathrm{C}$ in $\mathrm{CO}_{2}$ $10 \%$. The blastospore giving origin to the mycelial tube is swollen in comparison with the cluster of blastospores nearby. Growth in the control culture in air was entirely as blastospores. Wet preparation. Bar $=25 \mu \mathrm{m}$.

other amino acid with an amide side chain, asparagine, were included. Horse serum provided a reference medium and bovine albumin was used as a control for some of the numerous possible inducers in serum, e.g., urea.

Initial work with a medium containing urea as the nitrogen source showed that to induce good myce- 


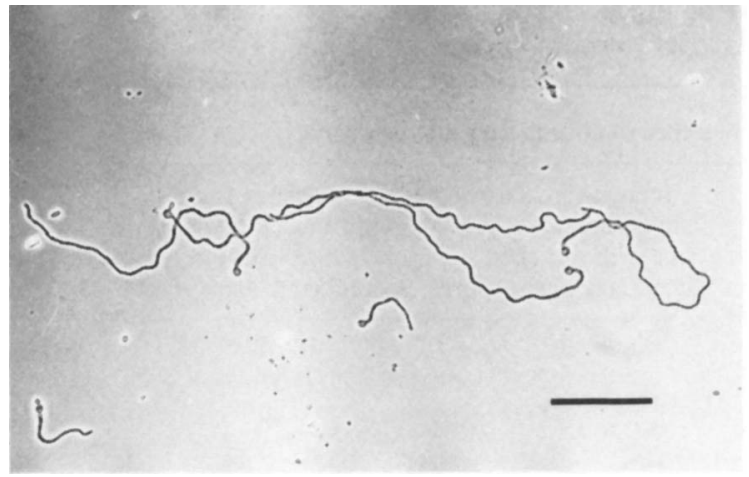

Fig. 3. C. albicans (oral strain Ac 1) incubated in the basal medium with ammonium chloride as the nitrogen source and bovine albumin as inducer for $18 \mathrm{~h}$ at $30 \mathrm{C}$ in $\mathrm{CO}_{2} 10^{\circ}$. Control culture in air consisted of blastospores only. Wet preparation. $\mathrm{Bar}=100 \mu \mathrm{m}$.

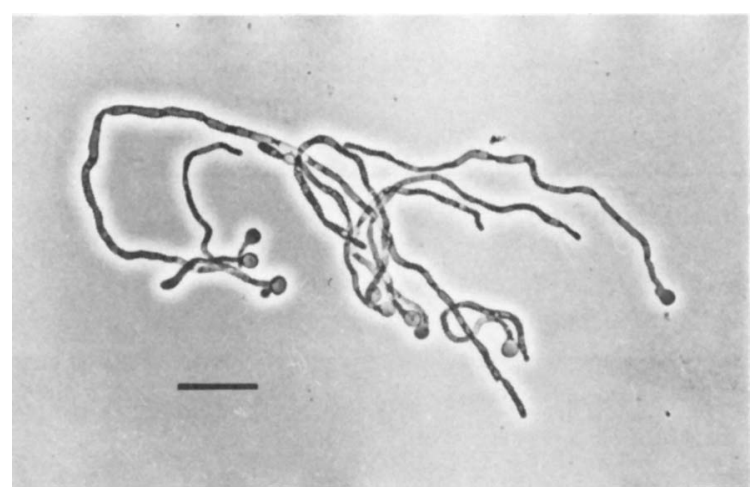

Fig. 4 C. albicans (oral strain N4) incubated in the basal medium with urea as the nitrogen source for $18 \mathrm{~h}$ at $30 \mathrm{C}$ in $\mathrm{CO}_{2} 10^{\circ}$, showing vacuoles in the mycelial tubes and the original blastospores. Wet preparation. Bar $=20 \mu \mathrm{m}$.

lial growth it was important to keep the glucose concentration below $0.2 \%$ and the $p \mathrm{H}$ above 5.7. The medium used in this study was formulated to have an initial $p \mathrm{H}$ near neutrality with any of the nitrogen sources and to remain little changed after growth of $\mathrm{C}$. albicans. The $p \mathrm{H}$ values of the $18-\mathrm{h}$ cultures were all within \pm 0.3 of the initial $p \mathrm{H}$.

Adding sodium bicarbonate to any of the media. up to a concentration of $1 \%$, had no effect on mycelium formation by any of the strains, a finding similar to that recently reported by Klotz et al. (1984) who also found that only gaseous $\mathrm{CO}_{2}$ influenced the morphology of Coccidioides immitis.

Two bovine-serum-albumin powders, azo-albumin and egg albumin (Sigma A-2153, A-4503, A2392 and A-5378 respectively) were effective inducers whereas crystallised and lyophillised bovine albumins and a globulin (Sigma A-4378, A-
7638 and G-5009) were not. No explanation of these differences can be offered. The ineffective preparation A-7638 is a more purified form of A-4503. Egg albumin was a potent inducer despite being crystallised and lyophillised. Some of the preparations were acidic but the $p \mathrm{H}$ of the medium was still above 6.8. Neither the effective albumin (A4503) nor the ineffective albumin (A-7638) were reduced in concentration in cultures incubated for $18 \mathrm{~h}$ at $37^{\circ} \mathrm{C}$ in air or air plus $\mathrm{CO}_{2} 10 \%$. There was no statistical difference between the mean concentration of protein in the cultures and in the uninoculated controls. This confirms the findings of Bernander and Edebo (1969) and Barlow et al. (1974).

\section{Effect of $\mathrm{CO}_{2}$ on blastospore growth}

Table II shows the effect of $\mathrm{CO}_{2}$ on the growth of 22 strains of $C$. albicans that grew mainly as blastospores in the medium containing ammonium chloride as the nitrogen source. The ranges reflect the variations in growth rate of the individual strains and although the differences in mean absorbence are quite small they are consistently larger in the cultures incubated in $\mathrm{CO}_{2} 10 \%$. In only five of the 18 -h cultures incubated at $37^{\circ} \mathrm{C}$ was growth less in $\mathrm{CO}_{2} 10 \%$. Analysis of the mean difference of the paired observations for each strain shows the differences to be significant $(\mathrm{p}<0.001)$ for all incubation times at both temperatures. Clearly, $\mathrm{CO}_{2}$

Table II. The absorbence of cultures of 22 strains of $C$. albicans growing in the basal medium + $\mathrm{NH}_{4} \mathrm{Cl} 1 \%$ incubated in air and air $+\mathrm{CO}_{2} 10 \%$

\begin{tabular}{|c|c|c|c|c|}
\hline $\begin{array}{l}\text { Temperature } \\
\text { (C) }\end{array}$ & $\begin{array}{l}\text { Time } \\
\text { (h) }\end{array}$ & Atmosphere & $\begin{array}{c}\text { Mean } \\
\text { absorbence }\end{array}$ & Range \\
\hline \multirow{8}{*}{30} & \multirow[t]{2}{*}{4} & Air & $0 \cdot 104$ & 0.089 \\
\hline & & $\mathrm{CO}_{2}$ & 0.112 & 0.093 \\
\hline & \multirow[t]{2}{*}{8} & Air & 0.208 & $0 \cdot 116$ \\
\hline & & $\mathrm{CO}_{2}$ & 0.220 & $0 \cdot 117$ \\
\hline & \multirow[t]{2}{*}{12} & Air & 0.314 & 0.135 \\
\hline & & $\mathrm{CO}_{2}$ & 0.325 & 0.147 \\
\hline & \multirow[t]{2}{*}{18} & Air & 0.442 & $0 \cdot 132$ \\
\hline & & $\mathrm{CO}_{2}$ & 0.454 & $0 \cdot 140$ \\
\hline \multirow{8}{*}{37} & \multirow[t]{2}{*}{4} & Air & $0 \cdot 115$ & 0.082 \\
\hline & & $\mathrm{CO}_{2}$ & $0 \cdot 124$ & 0.082 \\
\hline & \multirow[t]{2}{*}{8} & Air & 0.226 & $0 \cdot 104$ \\
\hline & & $\mathrm{CO}_{2}$ & $0 \cdot 241$ & $0 \cdot 102$ \\
\hline & \multirow[t]{2}{*}{12} & Air & 0.354 & $0 \cdot 106$ \\
\hline & & $\mathrm{CO}_{2}$ & 0.369 & $0 \cdot 112$ \\
\hline & \multirow[t]{2}{*}{18} & Air & 0.472 & 0.047 \\
\hline & & $\mathrm{CO}_{2}$ & 0.485 & $0 \cdot 054$ \\
\hline
\end{tabular}


rates the metabolism of $C$. albicans as well as promoting the mycelial form of growth. This organism also grows more rapidly at $37^{\circ} \mathrm{C}$ than at $30^{\circ} \mathrm{C}$.

\section{Effect of $\mathrm{CO}_{2}$ on germ-tube formation on glucose agar}

To produce germ-tubes on glucose agar (Joshi et al., 1975) the inoculated streak of $C$. albicans is covered with a coverslip. These authors stated that the effect of the coverslip was to create local anaerobiosis which promoted the formation of germ-tubes. With the 32 strains in this study it was confirmed that plates inoculated according to this technique and incubated in air produced germtubes, as expected, only beneath the coverslip. On plates incubated in air plus $\mathrm{CO}_{2} \quad 10 \%$ germ-tubes formed more abundantly in the uncovered streaked growth than under the coverslip. In anaerobic conditions growth was feeble and entirely as blastospores. In anaerobic conditions with $\mathrm{CO}_{2} 10 \%$, growth was still feeble; only an occasional short germ-tube was seen both under the coverslip and in the uncovered growth. These results strongly suggest that the effect of the coverslip in this technique is not the creation of anaerobiosis but the trapping of $\mathrm{CO}_{2}$ produced by the metabolism of the organism which then promotes the formation of germ-tubes.

\section{Discussion}

At $30^{\circ} \mathrm{C}$ none of the compounds tested in this study (table I) induced germ-tubes and mycelial growth of $C$. albicans, yet simply raising the partial pressure of $\mathrm{CO}_{2}$ converted them to potent inducers. Since these compounds were supporting satisfactory blastospore growth at this temperature, some general physical change seems a more likely cause of mycelial growth than the specific nutritional effects widely suggested in the past. The fact that albumin, a potent, reliable inducer, was unaltered in concentration in the cultures, as was previously observed by Bernando and Edebo (1969) and Barlow et al. (1974), supports this view. Furthermore, because albumin is effective at $37^{\circ} \mathrm{C}$ without extra $\mathrm{CO}_{2}$ and without being reduced in concentration, it seems reasonable to suggest that the effect is physical and that atmospheric concentrations of $\mathrm{CO}_{2}$ are sufficient to mediate it. Much of the controversy concerning the induction of germ-tubes seems to have arisen from attempting to explain the same physical phenomenon in nutritional and other terms. For example, Joshi et al. (1975) thought anaerobiosis caused by occlusion with a coverslip an essential feature for germ-tube production wher- eas Lee et al. (1975) could produce germ-tubes only by aerating the liquid form of their amino-acid medium which failed to induce germ-tubes when dispensed as plates. These apparently contradictory papers can be reconciled by the explanation that, in both cases, the crucial feature was an increased concentration of $\mathrm{CO}_{2}$. The results presented here strongly suggest that it is the trapping of $\mathrm{CO}_{2}$ under the coverslip and not anaerobiosis that induces germ-tubes in the technique of Joshi et al. (1975). Similarly, since $\mathrm{CO}_{2}$ is more than twenty times more soluble than $\mathrm{O}_{2}$ at $37^{\circ} \mathrm{C}$, the results of Lee et al. (1975) are more logically explained by an increased concentration of $\mathrm{CO}_{2}$ in the aerated liquid cultures over that at the surface of an agar plate than by a corresponding increase in $\mathrm{O}_{2}$.

There appears to be a rough inverse relationship between the growth temperature and the concentration of $\mathrm{CO}_{2}$ required to induce mycelial growth suggesting that the internal concentration of $\mathrm{CO}_{2}$ is the critical factor, whether achieved by raising the external pressure or internal metabolism. Because bicarbonate ions were without effect, it appears that the dissolved gas is involved. The way in which $\mathrm{CO}_{2}$ and the inducer compounds are corporately concerned is a matter for conjecture. In the case of albumin, a known carrier of various molecules, some loose binding of $\mathrm{CO}_{2}$ may occur creating an environment of increased $\mathrm{CO}_{2}$ tension around the organisms. The albumin preparations that failed to induce germ-tubes remained ineffective with $\mathrm{CO}_{2}$ $10 \%$, which is in keeping with the notion that induction involves reaction with $\mathrm{CO}_{2}$. The amide compounds tested, which, unlike albumin, are metabolised, seem more likely to function by raising the $\mathrm{CO}_{2}$ level within the fungal cells.

Gow and Gooday (1984) have shown that the swollen blastospores of origin and the elongated mycelial cells contain large vacuoles; the cytoplasm is little more than a thin rim between the vacuole and the cell wall. This arrangement would be advantageous in poorly nutrient conditions, which many believe important in germ-tube induction, because the cytoplasm is maximally spread for absorption of nutrients and the elongating mycelium effects physical removal to possibly more plentiful conditions. These vacuoles may be formed in response to raised $\mathrm{CO}_{2}$ partial pressures and their contents may be largely dissolved $\mathrm{CO}_{2}$. Once a large vacuole had formed in a blastospore, considerations of surface tension and surface to volume ratio would preclude budding to form a roughly spherical cell of smaller diameter than the mother cell. A cylindrical cell of smaller diameter than the parent cell could form and this could elongate 
indefinitely without altering its surface to volume ratio. Gow and Gooday (1984) found that secondary budding and branch formation could only occur from mycelial cells whose vacuoles had become refilled with cytoplasm. This favours the idea that the vacuoles form in response to $\mathrm{CO}_{2}$ partial pressure because in this work, long unbranched mycelial tubes were a striking feature of $C$. albicans growing in $\mathrm{CO}_{2} 10 \%$.

Although there are several reports of concentrations of $\mathrm{CO}_{2}$ above those in the normal atmosphere affecting the morphology of fungi in general, a recent extensive review of the literature concerned with the morphogenesis of $C$. albicans (Odds, 1985) cites only one report of $\mathrm{CO}_{2}$ altering the growth form (Mardon et al., 1969). This work involved a single, variant strain of $C$. albicans that did not form germ-tubes or chlamydospores and was grown in a medium of $p \mathrm{H} 4.5$ containing glucose $2.5 \%$ incubated at $28^{\circ} \mathrm{C}$ in $\mathrm{CO}_{2}$ concentrations twice that of oxygen. Despite doubts about the identity of the strain used and differences in the important parameters of $p \mathrm{H}$ and glucose concentration, the conclusion that $\mathrm{CO}_{2}$ promotes mycelial growth is fully endorsed by the results presented here. At the conclusion of his excellent review Odds (1985) states that notwithstanding the numerous papers devoted to the subject the factors affecting the morphogenesis of $C$. albicans remain largely speculative and yet the explanation could be paradoxically simple. The results of this work and other papers where the

\section{REFERENCES}

Aly R, Maibach H 1983 Susceptibility to skin infection. In: Rook A J, Maibach H I (ed) Recent advances in dermatology No 6. Churchill Livingstone, Edinburgh, pp 75-94.

Barlow A J E, Aldersley T, Chattaway F W 1974 Factors present in serum and seminal plasma which promote germ-tube formation and mycelial growth of Candida albicans. Journal of General Microbiology 82:261 272

Bernander S, Edebo L 1969 Growth and phase conversion of Candida albicans in Dubos medium. Sabouraudia 7:146. 155

Frame G W. Strauss W G, Maibach H 11972 Carbon dioxide emission of the human arm and hand. Journal of Intestigatite Dermatology 59:155-159.

Gow N A R, Gooday G W 1984 A model for the germ tube formation and mycelial growth form of Candida albicans. Sabouraudia 22:137-143.

Joshi K R, Bremner D A. Parr D N. Gavin J B 1975 The morphological identification of pathogenic yeasts using carbohydrate media. Journal of Clinical Pathology 28:1824

Klotz S A. Drutz. D J, Huppert M. Sun SH, DeMarsh P L 1984 The critical role of $\mathrm{CO}_{2}$ in the morphogenesis of Coccidiodes immitis in cell-free subcutaneous chambers. The Journal of Infectious Diseases 150:127 134 . possible effect of $\mathrm{CO}_{2}$ has not been considered suggest that $\mathrm{CO}_{2}$ tension could provide that simple explanation.

Clinically, the association between candidiasis and localised accumulations of $\mathrm{CO}_{2}$ is remarkably good. Frame et al. (1972) have shown that $\mathrm{CO}_{2}$ is continually diffusing through the skin and the rate of diffusion increases three fold through wet skin. Comparable measurements for mucous membranes do not appear to have been made but are unlikely to be less than those for wet skin. Aly and Maibach (1983) state that when the skin is covered with an occlusive dressing the concentration of $\mathrm{CO}_{2}$ under the dressing equilibrates with that of the underlying tissues in a few hours and amounts to $5-7 \%$. Examples of occlusion leading to candidiasis range from clinical experiments to the wearing of a wristwatch (reviewed by Odds, 1979), but probably the clearest and simplest involve the covering of the palate with a denture or orthodontic plate. In many cases of denture candidiasis and in probably all of the examples of children wearing orthodontic appliances there is no evidence of predisposing debilitation. Ceasing to wear the appliance cures the candidiasis. Shielding of the palatal flora from the forces of mechanical removal and cleansing is, clearly, one factor in these infections but the trapping of $\mathrm{CO}_{2}$ with consequent stimulation of the growth of $C$. albicans in general and the promotion of the mycelial form of growth in particular is, surely, another.

Lee K L, Buckley H R, Campbell C C 1975 An amino acid liquid synthetic medium for the development of mycelial and yeast forms of Candida albicans. Sahouraudia 13:148-153.

Mardon D N. Balish E, Phillips A W 1969 Control of dimorphism in a biochemical variant of Candida albicans. Journal of Bacteriology 100:701 707.

Odds F C 1979 Candida and candidosis. Leicester University Press, Leicester, pp 31 and 81 .

Odds F C 1985 Morphogenesis in Candida albicans. CRC Critical Reviews in Microbiology 12:45-93.

Odds F C , Abbott A B 1980 A simple system for the presumptive identification of Candida albicans and differentiation of strains within the species. Sabouraudia 18:301-317.

Ohnishi S T, Barr J K 1978 A simplified method of quantitating protein using the biuret and phenol reagents. Analytical Biochemistry 86:193-200.

Rosenthal S A, Furnari D 1958 Slide agglutination as a presumptive test in the laboratory diagnosis of Candida albicans. Journal of Investigative Dermatology 31:251-253.

Shepherd M G, Yin C Y, Ram S P, Sullivan P A 1980 Germ tube induction in Candida albicans. Canadian Journal of Microbiology 26:21 -26 .

Taschdjian C L, Burchall J J, Kozinn P J 1960 Rapid identification of Candida albicans by filamentation on serum and serum substitutes. American Journal of Diseaser of Children 99:212-215 